\title{
Adverse reactions of dimethyl sulfoxide in humans: a
}

\section{systematic review [version 1; peer review: 2 approved with}

\section{reservations]}

\author{
Bennedikte Kollerup Madsen (D), Maria Hilscher, Dennis Zetner (iD, \\ Jacob Rosenberg
}

Department of Surgery, Centre for Perioperative Optimization (CPO), Herlev Hospital, Herlev, 2730, Denmark

\author{
V1 First published: 05 Nov 2018, 7:1746 \\ https://doi.org/10.12688/f1000research.16642.1 \\ Latest published: 06 Aug 2019, 7:1746 \\ https://doi.org/10.12688/f1000research.16642.2
}

\section{Abstract}

Background: Dimethyl sulfoxide (DMSO) has been used for medical treatment and as a pharmacological agent in humans since the 1960s. Today, DMSO is used mostly for cryopreservation of stem cells, treatment of interstitial cystitis, and as a penetrating vehicle for various drugs. Many adverse reactions have been described in relation to the use of DMSO, but to our knowledge, no overview of the existing literature has been made. Our aim was to conduct a systematic review describing the adverse reactions observed in humans in relation to the use of DMSO.

Methods: This systematic review was reported according to the PRISMA-harms (Preferred Reporting Items for Systematic reviews and Meta-Analysis) guidelines. The primary outcome was any adverse reactions occurring in humans in relation to the use of DMSO. We included all original studies that reported adverse events due to the administration of DMSO, and that had a population of five or more. Results: We included a total of 109 studies. Gastrointestinal and skin reactions were the commonest reported adverse reactions to DMSO. Most reactions were transient without need for intervention. A relationship between the dose of DMSO given and the occurrence of adverse reactions was seen.

Conclusions: DMSO may cause a variety of adverse reactions that are mostly transient and mild. The dose of DMSO plays an important role in the occurrence of adverse reactions. DMSO seems to be safe to use in small doses.

Registration: PROSPERO CRD42018096117.

Keywords

Dimethyl Sulfoxide, DMSO, Adverse reactions, Toxicology

\section{Open Peer Review}

Approval Status

1 2

version 2

(revision)

06 Aug 2019

version 1

05 Nov 2018

$\begin{array}{cc}\checkmark & \\ \text { view } & \text { view } \\ ? & ? \\ \text { view } & \text { view }\end{array}$

1. Curly Morris, Queen's University Belfast, Belfast, UK

2. Igho J. Onakpoya (D), University of Oxford, Oxford, UK

Any reports and responses or comments on the article can be found at the end of the article. 
Corresponding author: Bennedikte Kollerup Madsen (Benedikte.kollerupmadsen@gmail.com)

Author roles: Kollerup Madsen B: Conceptualization, Data Curation, Formal Analysis, Investigation, Methodology, Project Administration, Validation, Visualization, Writing - Original Draft Preparation, Writing - Review \& Editing; Hilscher M: Data Curation, Formal Analysis, Investigation, Validation, Writing - Original Draft Preparation, Writing - Review \& Editing; Zetner D: Conceptualization, Formal Analysis, Investigation, Methodology, Supervision, Validation, Writing - Original Draft Preparation, Writing - Review \& Editing; Rosenberg J: Conceptualization, Formal Analysis, Investigation, Methodology, Project Administration, Supervision, Validation, Writing Original Draft Preparation, Writing - Review \& Editing

Competing interests: No competing interests were disclosed.

Grant information: The author(s) declared that no grants were involved in supporting this work.

Copyright: $\odot 2018$ Kollerup Madsen B et al. This is an open access article distributed under the terms of the Creative Commons Attribution License, which permits unrestricted use, distribution, and reproduction in any medium, provided the original work is properly cited.

How to cite this article: Kollerup Madsen B, Hilscher M, Zetner D and Rosenberg J. Adverse reactions of dimethyl sulfoxide in humans: a systematic review [version 1; peer review: 2 approved with reservations] F1000Research 2018, 7:1746

https://doi.org/10.12688/f1000research.16642.1

First published: 05 Nov 2018, 7:1746 https://doi.org/10.12688/f1000research.16642.1 


\section{Introduction}

The first medical report on the use of dimethyl sulfoxide (DMSO) as a pharmacological agent was published in $1964^{1}$. A year later, the use of DMSO in humans was terminated because experimental studies had shown refractive index changes to the lens of the eye $\mathrm{e}^{1,2}$. Years later, DMSO was again approved for use in humans since this side effect was only proven in animal studies $^{2}$. DMSO has since been used for a variety of purposes, such as treatment of musculoskeletal and dermatological diseases, cryopreservation of stem cells, treatment of interstitial cystitis, treatment of increased intracranial pressure, and many more ${ }^{3-9}$.

DMSO is a colourless liquid, which is rapidly absorbed when administered dermally or orally ${ }^{10,11}$. DMSO is used as a cryoprotectant because it decreases osmotic stress and cellular dehydration, and thereby enables stem cells to be stored for several years ${ }^{12}$. DMSO is mostly excreted through the kidneys, but a small part is excreted through the lungs and $\operatorname{liver}^{10}$. Part of the DMSO is transformed to the volatile metabolite dimethyl sulfide, which gives a characteristic garlic- or oyster-like smell when excreted through the lungs ${ }^{10}$. DMSO may induce histamine release, which can be the reason for adverse reactions such as flushing, dyspnoea, abdominal cramps, and cardiovascular reactions ${ }^{11}$.

To our knowledge, no systematic reviews have been performed on the adverse reactions of DMSO. Our aim was therefore to provide an extensive overview of the possible adverse reactions to DMSO in humans.

\section{Methods}

Protocol and eligibility criteria

Our study-protocol is registered at PROSPERO (Registration number: CRD42018096117). The systematic review was performed according to PRISMA-harms (Preferred Reporting Items for Systematic Reviews and Meta-Analyses) guidelines ${ }^{13}$.

No limitations were set on the date of publication. The language was restricted to English, Danish, Swedish, Norwegian, and Russian. We included all original studies that administered DMSO to humans and included five or more participants. There was no gender or age restriction. For a study to be included, the authors had to suspect that an observed adverse reaction could be caused by DMSO.

\section{Primary outcome}

The primary outcome was any adverse reaction seen in relation to the use of DMSO in humans.

\section{Literature search}

The search was performed in PubMed (1966-present), EMBASE (1980-present), and the Cochrane Library. The databases were last searched on February 23, 2018. Our search strategy was formulated with the help of a medical research librarian.

The search string used in PubMed was: ((dimethyl sulfoxide) OR DMSO) AND ((()((administration and dosage) OR adverse reactions) $\mathrm{OR}$ alternate effects) $\mathrm{OR}$ secondary response) $\mathrm{OR}$ toxicology) OR side effects)). The search was restricted to humans. The search string was adapted to EMBASE and Cochrane Library using the same search-words as abovementioned.

The search string used in EMBASE was: ((dmso or dimethyl sulfoxide) and ((side effect or toxicology or secondary response or alternate effects or alternate reactions or (administration and dosage)) and (dmso or dimethyl sulfoxide))).mp. The search was restricted to humans, articles and medline journals were excluded.

The search string used in Cochrane was: (adverse drug events and dimethyl sulfoxide). The search was restricted to trials.

\section{Study selection and data extraction}

Two authors (B.K.M. and D.Z.) independently screened title and abstract according to the eligibility criteria using www. covidence.org. Discrepancies were resolved by discussion. One author screened the full-text articles (B.K.M.). Russian articles were screened by an author fluent in Russian (M.H.).

After the screening process was finished, all included studies were imported to an Excel sheet (Microsoft Excel 2016). Data extraction was performed by two authors. Data extracted were: author, publication year, country, study characteristics (study design, sample size, size of comparison group if present, time to follow-up), use of DMSO (reason for use, treatment duration, administration route, dose of DMSO), and adverse reactions observed (number of persons experiencing an adverse reaction, method of assessing, and duration of adverse reaction).

\section{Analysis}

The Newcastle-Ottawa-Scale was used to assess the risk of bias in non-randomized observational studies ${ }^{14}$. Risk of bias in randomized controlled trials was assessed using the Cochrane Handbook "Risk of Bias" assessment tool ${ }^{15}$. Risk of bias was assessed at the outcome level.

The primary summary measure was percentage of persons experiencing an adverse reaction, as well as the range in which a reaction occurred in the studies included. No meta-analysis and further summery measures were planned due to the expected large heterogeneity of the studies.

\section{Results}

\section{Study selection}

Our primary search identified 2599 studies (Figure 1). After the evaluation process, 109 studies were included in the final review ${ }^{2,4,6-9,16-118}$.

\section{Gastrointestinal reactions}

Gastrointestinal adverse reactions, possibly due to DMSO, were reported in 61 studies. Of these, 10 studies were randomized controlled trials ${ }^{16,30,33,55,57,59,67,79,93,95}, 49$ were cohort studies $2,4,7,9,18,19,23,25-27,29,35,38-43,45,46,48,50-54,58,60,66,68,699,71,73,83,85-88,90,94,97$ $, 98,101,104,105,112,113,115,118$, and 2 were case $\operatorname{series}^{84,109}$. Most studies 

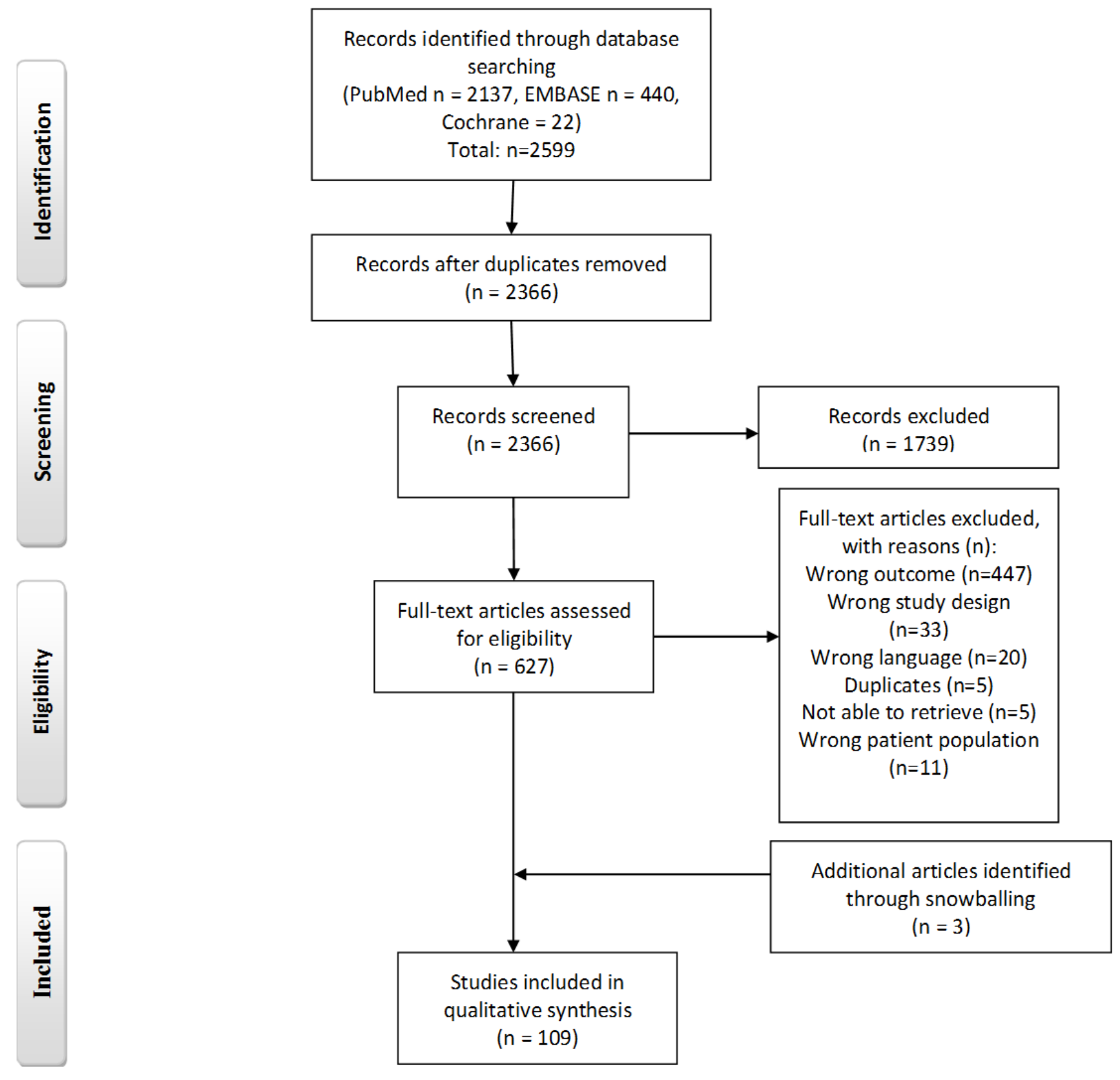

Figure 1. PRISMA flow diagram.

reported the number of patients experiencing an adverse reaction (Table 1). Other studies reported adverse reactions observed in relation to the number of treatments given (Table 2).

The most commonly reported gastrointestinal adverse reactions were nausea and vomiting. The incidence of nausea seems to be less common with the transdermal administration of DMSO compared with intravenous administration. The majority of studies reported an incidence of nausea between $2-14 \%$, with the exception of one study, reporting an incidence of $32 \%{ }^{2}$. In one study that failed to specify the dose, 8 of 42 patients reported nausea and anorexia, but the symptoms disappeared in five of the eight patients when the dose of DMSO was reduced ${ }^{45}$.

Often the studies had short follow-up periods (less than 24 hours), especially when DMSO was used as a cryoprotectant. The study reporting the highest incidence of nausea had a follow-up period of 5 days $^{48}$, and the authors concluded that the high incidence of nausea observed might be due to the long follow-up period ${ }^{48}$. In another article using the same data ${ }^{119}$, it was suggested that the delayed nausea was due to gastrointestinal mucosal damage, and only the initial nausea could be related to DMSO, and therefore 
Table 1. Gastrointestinal adverse reactions.

\begin{tabular}{|c|c|c|c|c|}
\hline Adverse reaction & Studies & $\begin{array}{l}\text { Total } \\
\text { patients, } \mathbf{n}\end{array}$ & $\begin{array}{l}\text { Patients } \\
\text { with adverse } \\
\text { reaction, } n(\%)\end{array}$ & $(\%$, min-max $) \dagger$ \\
\hline Nausea (overall incidence) & {$[2,18,27,33,45,46,48,53,55,57,59,60,67,84,90,93,109,118]$} & 2214 & $257(12)$ & $(2-41)[55]-[48]$ \\
\hline Intravenous administration & {$[18,27,33,46,48,53,59,90,118]$} & 1154 & $199(17)$ & $(2-41)[59]-[48]$ \\
\hline Transdermal application & {$[2,45,55,57,67,93,109]$} & 1039 & $51(5)$ & $(2-32)[55]-[2]$ \\
\hline$>1$ administration route & {$[60,84]$} & 21 & $7(33)$ & $(29-36)[84]-[60]$ \\
\hline Vomiting (overall incidence) & {$[2,18,27,33,46,48,55,57,59,118]$} & 1611 & $115(7)$ & $(0-64)[55]-[48]$ \\
\hline Intravenous administration & {$[18,27,33,46,48,59,118]$} & 972 & $108(11)$ & $(2-64)[59]-[48]$ \\
\hline Transdermal application & {$[2,55,57]$} & 639 & $7(1)$ & $(0-6)[55]-[2]$ \\
\hline Nausea and vomiting $\neq$ & {$[7,38,41,54,66,69,73,85,87,115]$} & 4529 & $591(13)$ & $(0-46)[66]-[73]$ \\
\hline $\begin{array}{l}\text { Abdominal cramps/stomach } \\
\text { ache (overall incidence) }\end{array}$ & {$[18,26,27,39,41,54,55,59,73,85,87,93,115]$} & 1629 & $88(5)$ & $(1-52)[117]-[116]$ \\
\hline Intravenous administration & {$[18,26,27,39,41,54,59,73,85,87,115]$} & 1253 & $72(6)$ & $(1-52)[18]-[26]$ \\
\hline Transdermal application & {$[55,93]$} & 376 & $16(4)$ & $(2-16)[55]-[93]$ \\
\hline $\begin{array}{l}\text { Halitosis/garlic-like breath } \\
\text { (overall incidence) }\end{array}$ & $\begin{array}{l}{[4,9,16,19,29,30,35,42,43,45,50,52,55,57,58,66-68,79,83} \\
85,88,94,95,97,98,109,112,113]\end{array}$ & 5782 & $607(11)$ & $\begin{array}{l}(0-100)[30]- \\
{[19,43,45,83,98]}\end{array}$ \\
\hline Intravenous administration & {$[16,85,94,98]$} & 239 & $14(6)$ & $(1-100)[85]-[98]$ \\
\hline Transdermal application & $\begin{array}{l}{[4,19,29,30,42,45,50,52,55,57,58,66,67,79,83,88,95,109,} \\
112,113]\end{array}$ & 5333 & $556(10)$ & $\begin{array}{l}(0-100)[30] \\
-[19,45,83]\end{array}$ \\
\hline Intravesical administration & {$[35,43,97]$} & 165 & $33(20)$ & $(1-100)[35]-[43]$ \\
\hline Oral administration & [9] & 15 & $4(27)$ & \\
\hline Diarrhea (overall incidence) & {$[2,18,41,54,57,85,93]$} & 1107 & $27(2)$ & $(1-6)[85]-[93]$ \\
\hline Intravenous administration & {$[18,41,54,85]$} & 744 & $15(2)$ & $(1-6)[85]-[41]$ \\
\hline Transdermal application & {$[2,57,93]$} & 363 & $12(3)$ & $(2-6)[57]-[93]$ \\
\hline
\end{tabular}

†ncidences of the adverse reactions have been calculated for all the individual studies. (min\%-max\%) are the lowest and highest observed incidence of an adverse reaction observed in the group of studies included.

‡ Nausea and vomiting are reported as one combined adverse reaction in some studies.

Table 2. Gastrointestinal adverse reactions.

\begin{tabular}{|c|c|c|c|c|}
\hline Adverse reaction & Studies & $\begin{array}{l}\text { Total } \\
\text { treatments, } \mathrm{n}\end{array}$ & $\begin{array}{l}\text { Adverse reactions } \\
\text { observed, } \mathrm{n}(\%)\end{array}$ & $(\min \%-\max \%) \dagger$ \\
\hline Nausea (overall incidence) & {$[40,51,68,84,105]$} & 474 & $161(34)$ & $(16-57)[105]-[40]$ \\
\hline Intravenous administration & {$[40,51,68]$} & 323 & $137(42)$ & $(41-57)[68]-[40]$ \\
\hline Intravesical administration & {$[105]$} & 151 & $24(16)$ & \\
\hline Vomiting $\neq$ & {$[51,68]$} & 316 & $112(35)$ & $(29-71)[68]-[51]$ \\
\hline Nausea and/or vomiting $\ddagger$ & {$[25,74,101]$} & 1557 & $220(14)$ & $(8-17)[25]-[101]$ \\
\hline Abdominal cramps/stomach ache $\ddagger$ & {$[51,68,101]$} & 495 & $16(5)$ & $(1-19)[68]-[51]$ \\
\hline Halitosis ¥ & [68] & 262 & $4(2)$ & \\
\hline Diarrhea $\ddagger$ & {$[51,101]$} & 233 & $2(1)$ & $(1-2)[101]-[51]$ \\
\hline
\end{tabular}

$\dagger$ Incidences of the adverse reactions have been calculated for all the individual studies. (min\%-max\%) are the lowest and highest observed incidence of an adverse reaction.

$\ddagger$ Intravenous administration. 
we decided only to include the data from the first 2 days after infusion ${ }^{48}$.

Halitosis was reported in 29 studies $^{4,9,16,19,29,30,35,42,43,45,50,52,55,57,58,66-}$ $68,79,83,85,88,94,95,97,98,109,112,113$. In some studies, patients discontinued treatment due to halitosis ${ }^{9,45,83,94}$. In five studies, all patients experienced halitosis ${ }^{9,45,83,94}$. Unlike halitosis, other gastrointestinal side effects were reported more often when DMSO was administered intravenously, than transdermally or intravesically.

One study reported a severe case of nausea, vomiting, and abdominal cramps in one patient with an acute allergic reaction ${ }^{59}$. However, in most studies the reported gastrointestinal reactions were transient and mild, often lasting only minutes to a couple of hours ${ }^{16,38,41,68,85,87,90}$. Several studies reported a relationship between the dose of DMSO and the occurrence of gastrointestinal adverse reactions ${ }^{26,33,53,73,83,85}$.

Cardiovascular and respiratory reactions

Cardiovascular and respiratory adverse reactions were reported in 33 studies. Of these, two were randomized controlled trials $^{33,59}, 30$ were cohort studies $\mathrm{s}^{7,18,23,25-27,36,39-41,51,54,61,65,66,68,73,74,80,85}$ $-87,90,100-102,104,115,117$, and one was a preliminary report ${ }^{91}$. Except for one study ${ }^{66}$, all studies reporting cardiovascular and respiratory reactions administered DMSO intravenously (Table 3 and Table 4).

Bradycardia was defined as a heart rate less than 60 beats per minute $^{41,61}$ and was often transient ${ }^{23,61,90,115}$, but cases where atropine was needed are described ${ }^{49,96}$. A lowered heart rate not enough to be considered bradycardia was observed in four studies $^{39,41,54,61}$.

In some studies, hypertension did not require intervention ${ }^{61,102}$, but cases where medication was needed to control the hypertension, or where treatment was stopped due to hypertension, are described ${ }^{41,54,85}$. Hypotension was also described as transient most of the time ${ }^{18,23,68,87,104}$, with some cases needing intervention $^{40,51,54}$.

One study reported 11 cases of transient extrasystoles in 22 patients receiving cryopreserved autologous blood stem cells, monitored with Holter during infusion ${ }^{73}$. There were two studies reporting cases of asystole during embolization of dural arteriovenous fistulas with a substance called Onyx, a nonadhesive liquid embolic agent dissolved in $\mathrm{DMSO}^{91,100}$.

Table 3. Cardiovascular and respiratory adverse reactions.

\begin{tabular}{|c|c|c|c|c|}
\hline Adverse reaction & Studies & $\begin{array}{l}\text { Total } \\
\text { patients, } \mathrm{n}\end{array}$ & $\begin{array}{l}\text { Patients with adverse } \\
\text { reactions, } \mathrm{n}(\%)\end{array}$ & $(\min \%-\max \%) \dagger$ \\
\hline \multicolumn{5}{|l|}{ Cardiac } \\
\hline Hypotension $\neq$ & {$[7,18,23,33,71,73,87,104,115]$} & 2752 & $115(4)$ & $(1-14)[18,71]-[87]$ \\
\hline Hypertension $\S$ & {$[7,18,23,33,41,54,61,73,85,87,102]$} & 2998 & $385(13)$ & $(2-95)[85]-[61]$ \\
\hline Bradycardia (mild and severe) $\neq$ & {$[23,36,54,61,65,85,90,91,115,117]$} & 882 & $94(11)$ & $(0-49)[36]-[61]$ \\
\hline Decrease in heart rate $\neq$ & {$[41,54,61,80]$} & 193 & $152(79)$ & $(11-94)[80]-[41]$ \\
\hline Tachycardia $\neq$ & {$[23,27,36]$} & 565 & $13(2)$ & $(0-6)[36]-[23]$ \\
\hline Ventricular extrasystoles $\neq$ & [73] & 22 & $11(50)$ & \\
\hline Cardiac event, unspecified $\neq$ & {$[26,86]$} & 165 & $18(11)$ & $(5-12)[26]-[86]$ \\
\hline Asystole ๆ & {$[91,100]$} & 45 & $3(7)$ & $(3-20)[100]-[91]$ \\
\hline Left cardiac insufficiency & [85] & 194 & $1(1)$ & \\
\hline Chest discomfort/tightness $\ddagger$ & {$[18,27,54,73,87,91,115]$} & 901 & $22(2)$ & $(1-10)[27]-[54]$ \\
\hline \multicolumn{5}{|l|}{ Respiratory } \\
\hline $\begin{array}{l}\text { Unspecified respiratory } \\
\text { symptoms } \ddagger\end{array}$ & {$[26,86]$} & 165 & $43(26)$ & $(21-62)[86]-[26]$ \\
\hline Dyspnea $^{d}$ & {$[18,27,54,66,85]$} & 2748 & $26(1)$ & $(0-10)[66]-[54]$ \\
\hline Cough & {$[85,101]$} & 373 & $52(14)$ & $(5-22)[101][85]$ \\
\hline Lung edema $\ddagger$ & {$[59,85]$} & 241 & $3(1)$ & $(1-2)[85]-[59]$ \\
\hline
\end{tabular}

†ncidences of the adverse reactions have been calculated for all the individual studies. (min\%-max\%) are the lowest and highest observed incidence of an adverse reaction.

† DMSO was administered intravenously in all studies.

§ DMSO was administered intravenously in all studies. Horacek et al. [58] measured 42 patients with an increase in systolic blood pressure, and 31 patients with an increase in diastolic blood pressure. This was counted as 73 cases of hypertension.

If In both studies, asystole occurred because of DMSO effect on the trigeminal nerve and activation of the trigeminal cardiac reflex. d) in one study DMSO was administered transdermally 
Table 4. Cardiovascular and respiratory adverse reactions.

\begin{tabular}{|c|c|c|c|c|}
\hline Adverse reaction & Studies & $\begin{array}{l}\text { Total number of } \\
\text { treatments }\end{array}$ & $\begin{array}{l}\text { Adverse reactions } \\
\text { observed, } \mathrm{n}(\%)\end{array}$ & $(\min \%-\max \%) \dagger$ \\
\hline \multicolumn{5}{|l|}{ Cardiac } \\
\hline Hypotension $\neq$ & {$[40,51,68]$} & 323 & $10(3)$ & $(2-14)[68]-[40]$ \\
\hline Hypertension $\neq$ & {$[25,51,68]$} & 425 & $60(14)$ & $(3-21)[25]-[68]$ \\
\hline Bradycardia (mild and severe) $\neq$ & [51] & 54 & $4(7)$ & \\
\hline Decrease in heartrate $\neq$ & [39] & 32 & $30(94)$ & \\
\hline Tachycardia $\neq$ & [51] & 54 & $4(7)$ & \\
\hline Cardiac event, unspecified $\ddagger$ & {$[74]$} & 1269 & $35(3)$ & \\
\hline Chest discomfort/tightness $\neq$ & {$[25,68,74]$} & 1640 & $83(5)$ & $(0-6)[68]-[74]$ \\
\hline \multicolumn{5}{|l|}{ Respiratory } \\
\hline Dyspnea & {$[25,68]$} & 371 & $3(1)$ & $(0-2)[68]-[25]$ \\
\hline Shortness of breath $\ddagger$ & [74] & 1269 & $40(3)$ & \\
\hline
\end{tabular}

Hncidences of the adverse reactions have been calculated for all the individual studies. (\%, min-max) are the lowest and highest observed incidence of an adverse reaction observed in the group of studies included.

‡ DMSO was administered intravenously.

Dyspnea was reported in seven studies ${ }^{18,25,27,54,66,68,85}$. A single study reported eight patients with transient shock after stem cell transfusion $^{51}$. Some of these patients developed loss of consciousness and cyanosis but recovered promptly and had no need for additional therapy, whereas the rest of the patients developed severe hypotension or transient dyspnea, which was described as the reason for the transient shock. Further description of the condition was not provided.

Several of the studies found a correlation between the dose of DMSO used and the incidence of cardiovascular adverse reactions $\mathrm{s}^{41,67,71,75,78,85,86,93,101,115}$.

\section{Dermatological reactions}

Dermatological side effects are common when DMSO is administered transdermally. Skin reactions or allergic reactions were reported in 58 studies. DMSO was applied transdermally in 43 studies $2,4,6,17,19-22,24,28-32,37,44,45,52,55,57,63,64,66,67,69,72,75,76,78,79,82,83,88,89,93,95,96$, $106,108,109,111-113$, intravenously in 14 studies $^{25,40,41,51,59,73,74,77,85,86,92,98,101,110}$ and intraarticular in one ${ }^{103}$ (Table 5).

The most common skin reaction was a local burning sensation reported in 13 studies ${ }^{17,21,24,28,30,45,55,57,67,69,79,93,106}$. In one study, all participants experienced this burning sensation ${ }^{45}$. In the same study, four participants experienced a transient peripheral edema associated with itching and erythema ${ }^{45}$. A single study described a burning sensation in four of 669 patients when DMSO was given as a local injection ${ }^{92}$; another study described burning in two out of 17 patients when DMSO was injected intraarticularly ${ }^{103}$.

Most skin reactions were transient, only lasting minutes ${ }^{17,24,32,67,72}$, but some studies reported cases described as serious, causing discontinuation of treatment ${ }^{2,6,52,63,78,96}$. There were two studies describing that skin reactions to DMSO would disappear after days of continuous treatment ${ }^{45,83}$. Another study reported that 1 of 18 patients treated for psoriasis with DMSO was hospitalized due to exfoliative erythroderma ${ }^{63}$. In another study, two patients, diagnosed with dermographia developed prominent areas of weals after DMSO application ${ }^{95}$.

Acute allergic reactions due to use of DMSO were reported in six studies $37,44,59,86,98,110$. One study reported that 63 of 144 patients experienced allergic reactions, which was not described as serious adverse events (bronchospasms, facial flushing, rash) ${ }^{86}$. In two other studies, acute allergic reactions were characterized as serious adverse events ${ }^{59,110}$.

Flushing was regarded as an allergic reaction in this review and was only reported when DMSO was administered intravenously ${ }^{25,40,41,51,54,73,74}$. A total of four studies, not depicted in Table 5, reported 204 cases of flushing during 1439 stem cell infusions ${ }^{25,40,51,74}$. Several studies observed a relationship between the dose of DMSO and the occurrence of adverse reactions $\mathbf{s}^{67,75,78,83,88,93}$.

\section{Neurological reactions}

Headache is the most common neurological adverse reaction reported. In one study, headache was the reason for withdrawal of 2 out of 21 patients being treated with $\mathrm{DMSO}^{116}$.

Three studies using DMSO as a cryoprotectant in stem cell transfusions described seizures after administration ${ }^{18,36,47}$. Severe encephalopathy was observed in one patient ${ }^{99}$, and transient cranial nerve III and IV palsy was observed in one patient after Onyx embolization ${ }^{34}$. One study described neurological symptoms occurring during and after transfusion, but they did not define neurological symptoms in detail ${ }^{86}$. 
Table 5. Dermatological and allergic adverse reactions.

\begin{tabular}{|c|c|c|c|c|}
\hline Adverse reactions & Studies & $\begin{array}{l}\text { Total } \\
\text { patients, } \mathrm{n}\end{array}$ & $\begin{array}{l}\text { Patients } \\
\text { with adverse } \\
\text { reactions, } \mathrm{n}(\%)\end{array}$ & $(\%, \min -\max ) \dagger$ \\
\hline \multicolumn{5}{|l|}{ Skin reactions } \\
\hline Erythema $\neq$ & {$[19,32,64,66,82,95]$} & 2352 & $201(9)$ & $(3-95)[95]-[82]$ \\
\hline Itching/Pruritus $\ddagger$ & {$[6,55,57,64,66,72,82,93]$} & 3421 & $215(6)$ & $(0-70)[55]-[82]$ \\
\hline Urticaria $\neq$ & {$[24,31,83]$} & 58 & $9(16)$ & $(4-59)[24]-[83]$ \\
\hline Rash & {$[29,30,55,57,64,93,101,111]$} & 2682 & $121(5)$ & $(1-40)[30]-[93]$ \\
\hline $\begin{array}{l}\text { Paresthesia/burning or } \\
\text { stinging sensation } \S \ddagger\end{array}$ & {$[17,21,24,28,30,44,45,55,57,67,69,79,91,93,106]$} & 2141 & $335(16)$ & $(0-100)[30]-[45]$ \\
\hline $\begin{array}{l}\text { Scaling of skin/desquamation/ } \\
\text { dry skin/local irritant } \neq\end{array}$ & {$[22,29,30,37,52,55,57,64,66,69,75,82,88,89,106]$} & 4739 & $731(15)$ & $(1-96)[66]-[52]$ \\
\hline Blistering $\neq$ & {$[31,32,66,69,93,112]$} & 2038 & $79(4)$ & $(3-20)[66]-[112]$ \\
\hline $\begin{array}{l}\text { Roughness and/or thickening } \\
\text { of skin } \neq\end{array}$ & {$[66,82,93]$} & 1986 & $191(10)$ & $(6-10)[93]-[82]$ \\
\hline $\begin{array}{l}\text { Bullous dermatitis/dermatitis } \\
\text { with vesicles } \neq\end{array}$ & {$[20,29,64]$} & 1116 & $79(7)$ & $(1-9)[64]-[29]$ \\
\hline Contact dermatitis $\neq$ & {$[6,20,28-30,64,111]$} & 2587 & $161(6)$ & $(1-13)[28]-[29]$ \\
\hline Skin reaction, unspecified $\neq$ & {$[2,78,96,113]$} & 457 & $159(35)$ & $(4-48)[96]-[113]$ \\
\hline Increase in skin pigmentation $\neq$ & [6] & 548 & $28(5)$ & \\
\hline Peripheral edema $\neq$ & {$[45,55,66,109]$} & 2291 & $22(0)$ & $(1-14)[66]-[109]$ \\
\hline Allergic reactions & {$[37,44,59,86,98,110]$} & 309 & $75(24)$ & $(3-55)[44,110]-[86]$ \\
\hline Intravenous administration & {$[59,86,98,110]$} & 229 & $66(29)$ & $(2-55)[59]-[86]$ \\
\hline Transdermal application & {$[37,44]$} & 86 & $9(10)$ & $(3-19)[44]-[37]$ \\
\hline Flushing ๆ & {$[41,54,73]$} & 292 & $34(12)$ & $(2-9)[54]-[73]$ \\
\hline
\end{tabular}

†ncidences of the adverse reactions have been calculated for all the individual studies. (min\%-max\%) are the lowest and highest observed incidence of an adverse reaction observed in the group of studies included.

$\neq$ Transdermal application only.

§ One study administered DMSO through intraarticular injection [38].

ๆ DMSO was administered intravenously in all studies.

\section{Urogenital reactions}

Few urogenital reactions were described (Table 6 and Table 7). Hemoglobinuria was described as an adverse reaction seen after transfusion of stem cell products ${ }^{39,51,56,73}$. However, hemoglobinuria is often attributed to erythrocyte debris in the transplant material and has thus not been interpreted as being caused by $\mathrm{DMSO}^{39,73}$. The other urogenital reactions (Table 6 and Table 7) all occurred after DMSO instillation in the bladder $^{38,49,97}$.

\section{Other reactions}

Only one study in this review administered DMSO as eyedrops ${ }^{114}$. In this study, two patients experienced severe conjunctival hyperemia due to allergic reactions, and $25 \%$ of patients experienced a stinging sensation when eye-drops were applied ${ }^{114}$. Other studies performed eye examinations to determine whether DMSO caused changes in the lens; however, no such cases were observed $^{2,45}$.
Hyponatremia occurred in six patients after they received large doses of DMSO as treatment for cranial hypertension ${ }^{62}$. This adverse reaction was not reported in other studies (Table 8).

Very few cases of serious adverse reactions associated with DMSO have been described ${ }^{18,36,51,59}$.

Risk of bias within studies

In this review, we included 76 cohort studies, of which 64 were prospective $2,4,6,7,20,22,24-27,29,31,32,34-38,40-45,48,50-54,56,58,60,63,65,66,68-70,72,73$, $77,80,81,83,85,88,90,92,94,97,98,101-104,107,108,110,112,115,117,118$ and 13 were retrospective $9,18,23,39,46,47,61,71,74,86,87,100,105$. Bias was assessed using The Newcastle-Ottawa-Scale ${ }^{14}$. Using this scale, studies were given zero to nine stars. A high number of stars equals low risk of bias and vice versa. The studies in this review had a median value of 5 stars, with a range of $2-8$. No studies received the highest possible value of nine stars. Very few studies had a comparison group that did not receive DMSO, and often the occurrence 
Table 6. Neurological and urogenital adverse reactions.

\begin{tabular}{|c|c|c|c|c|}
\hline Adverse reaction & Studies & $\begin{array}{l}\text { Total } \\
\text { patients, } \mathrm{n}\end{array}$ & $\begin{array}{l}\text { Patients } \\
\text { with adverse } \\
\text { reactions, } \mathrm{n}(\%)\end{array}$ & $(\min \%-\max \%)$ \\
\hline \multicolumn{5}{|l|}{ Neurological } \\
\hline Headache & {$[2,18,29,33,38,41,55,59,70,71,81,84,85,98,101,104,116]$} & 2516 & $150(6)$ & $(1-50)[101]-[70]$ \\
\hline Intravenous administration & {$[18,33,41,59,70,71,81,85,98,101,104]$} & 1271 & $42(3)$ & $(1-50)[101]-[70]$ \\
\hline Transdermal application & {$[2,29,55]$} & 1197 & $102(8)$ & $(5-35)[55]-[2]$ \\
\hline Intravesical administration & [38] & 20 & $1(5)$ & \\
\hline Rectal administration & [116] & 21 & $3(14)$ & \\
\hline$>1$ administration route & {$[84]$} & 7 & $2(29)$ & \\
\hline Seizures & {$[18,36,47]$} & 301 & $2(1)$ & $(0-2)[18]-[47]$ \\
\hline $\begin{array}{l}\text { Neurological symptoms, } \\
\text { unspecified }\end{array}$ & {$[86]$} & 144 & $5(3)$ & \\
\hline $\begin{array}{l}\text { Transient CN III and IV } \\
\text { palsy }\end{array}$ & [34] & 12 & $1(8)$ & \\
\hline Severe encephalopathy & [99] & 124 & $1(1)$ & \\
\hline \multicolumn{5}{|l|}{ Urogenital } \\
\hline $\begin{array}{l}\text { Pelvic discomfort/pain/ } \\
\text { irritation }\end{array}$ & {$[38,49,97]$} & 107 & $10(9)$ & $(6-30)[49]-[38]$ \\
\hline Dysuria/strangury & [49] & 36 & $6(17)$ & \\
\hline Renal and urinary disorder & [49] & 36 & $8(22)$ & \\
\hline
\end{tabular}

†Incidences of the adverse reactions have been calculated for all the individual studies. (min\%-max\%) are the lowest and highest observed incidence of an adverse reaction observed in the group of studies included.

Table 7. Neurological and urogenital adverse reactions.

\begin{tabular}{|l|l|l|l|l|}
\hline Adverse reaction & Studies & $\begin{array}{l}\text { Total } \\
\text { treatments, } \mathbf{n}\end{array}$ & $\begin{array}{l}\text { Adverse reactions } \\
\text { observed, } \mathbf{n}(\%)\end{array}$ & $(\mathbf{m i n} \%-$-max\%) \\
\hline Neurological & & & $40(47)$ & $(6-73)[39]-[51]$ \\
\hline Headache & {$[39,51]$} & 86 & & \\
\hline Urogenital & & & $110(73)$ & \\
\hline Urethral irritation & {$[73]$} & 151 &
\end{tabular}

†ncidences of the adverse reactions have been calculated for all the individual studies. (\%, min-max) are the lowest and highest observed incidence of an adverse reaction observed in the group of studies included.

Table 8. Other adverse reactions.

\begin{tabular}{|l|l|l|l|l|}
\hline $\begin{array}{l}\text { Adverse } \\
\text { reaction }\end{array}$ & Studies & $\begin{array}{l}\text { Total } \\
\text { patients, } \mathbf{n}\end{array}$ & $\begin{array}{l}\text { Patients with } \\
\text { reaction, } \mathbf{n}(\%)\end{array}$ & (min\%-max\%) \\
\hline Fever & {$[27,71,73,77,101]$} & 547 & $44(8)$ & $(2-19)[27]-[77]$ \\
\hline Chills & {$[27,33,70,71,81,85,101]$} & 852 & $60(7)$ & $(1-31)[101]-[71]$ \\
\hline Dizziness & {$[2,46,55,85,101]$} & 885 & $18(2)$ & $(1-15)[55]-[2]$ \\
\hline Weakness & {$[33,45,46]$} & 293 & $19(6)$ & $(1-29)[46]-[45]$ \\
\hline Sedation & {$[2]$} & 78 & $34(44)$ & \\
\hline Hyponatremia & {$[62]$} & 6 & $6(100)$ & \\
\hline
\end{tabular}

†ncidences of the adverse reactions have been calculated for all the individual studies. (\%, min-max) are the lowest and highest observed incidence of an adverse reaction observed in the group of studies included. 
of adverse reactions was poorly described. There were 24 randomized controlled trials (Figure 2). Many studies received an unclear risk of bias because often it was vaguely described how adverse reactions were reported.

Overall, there was a high risk of bias when assessing the description of adverse reactions. Some studies were not assessed for bias due to being case-reports, preliminary trials, or because they included more than one study design ${ }^{17,19,28,62,84,91,99,109,111,113}$.

\section{Discussion}

Gastrointestinal and dermatological adverse reactions were the most commonly reported in the included studies. Cardiac adverse reactions only occurred when DMSO was administered intravenously, whereas dermatological reactions mostly occurred when DMSO was administered on the skin. Serious neurological and cardiac reactions were rare and only described in few studies. There seems to be a dose-response relationship between
DMSO and adverse reactions with no or mild reactions in low doses.

Many studies on the use of DMSO have been performed in Russia. These studies have not been readily accessible to the global community due to the language barrier. In this review, we have included not only studies dating back almost 50 years, but also articles written in Russian, which is an important strength of the review. Some studies used the NCI-CTC (National Cancer Institute's Common Terminology Criteria for adverse events), but often no scale was used, and the occurrence of adverse reactions were poorly reported. It was difficult to make conclusions on the frequency of a specific adverse reaction, because the exact number of patients experiencing a reaction was often not stated. Also, several studies using DMSO as a cryoprotectant concluded that other factors affected the occurrence of adverse reactions ${ }^{7,85,86}$. One study prospectively looked at the adverse reactions observed in relation to autologous transplantation in 64

\begin{tabular}{|c|c|c|c|c|c|c|c|c|}
\hline & \multirow[b]{2}{*}{$\begin{array}{l}\text { Year of } \\
\text { publication }\end{array}$} & \multicolumn{7}{|c|}{ Bias domain } \\
\hline & & 1 & 2 & 3 & 4 & 5 & 6 & 7 \\
\hline Bookman et al. [57] & 2004 & $\odot$ & $\odot$ & $\odot$ & $\odot$ & $\odot$ & $?$ & $\odot$ \\
\hline Bosso et al. [82] & 1985 & $\odot$ & $\odot$ & & $?$ & $?$ & $?$ & $?$ \\
\hline Burton et al. [106] & 1981 & $?$ & $?$ & 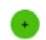 & $\odot$ & $?$ & $?$ & $?$ \\
\hline Cervigni et al. [49] & 2017 & $\odot$ & $\odot$ & & O & $\odot$ & $\odot$ & $?$ \\
\hline Dawber et al. [95] & 1974 & $\odot$ & $\odot$ & $\odot$ & $?$ & $?$ & $?$ & $?$ \\
\hline Garcia, C. [114] & 1983 & $?$ & $?$ & $?$ & $?$ & $?$ & $?$ & $?$ \\
\hline Matsumoto, J. [75] & 1967 & $?$ & $?$ & & $?$ & $?$ & $?$ & O \\
\hline Melikhova et al. [76] & 1986 & $?$ & $?$ & + & $?$ & $?$ & $?$ & $?$ \\
\hline Mitrus et al. [33] & 2017 & $?$ & $?$ & $\odot$ & $?$ & $\odot$ & $\odot$ & $?$ \\
\hline Peeker et al. [8] & 2000 & $?$ & $?$ & & $?$ & $?$ & $?$ & $?$ \\
\hline Percy, E. and Carson, J. [93] & 1981 & $\odot$ & $?$ & & ○ & $?$ & $?$ & $?$ \\
\hline Perez et al. [96] & 2003 & $?$ & $\odot$ & & $\odot$ & $?$ & $?$ & $?$ \\
\hline Roth, S. and Fuller, P. [64] & 2012 & $?$ & $?$ & $\odot$ & $?$ & $?$ & $?$ & $?$ \\
\hline Roth, S. and Shainhouse, J. [55] & 2004 & $\odot$ & $\odot$ & $\odot$ & $\odot$ & $?$ & $?$ & $?$ \\
\hline Salim, A. [116] & 1991 & $\odot$ & $?$ & $?$ & $?$ & $?$ & $?$ & $?$ \\
\hline Shpall et al. [59] & 1997 & $?$ & $?$ & $?$ & $?$ & $?$ & $?$ & $?$ \\
\hline Simon et al. [30] & 2009 & $\odot$ & $\odot$ & $\odot$ & $\odot$ & $?$ & $?$ & $?$ \\
\hline Simpson, J. [79] & 1975 & $?$ & $?$ & $?$ & $?$ & $?$ & $?$ & $?$ \\
\hline Spruance et al. [67] & 1990 & $\odot$ & $?$ & $\odot$ & $?$ & $?$ & $?$ & $?$ \\
\hline Vadhan-Raj et al. [16] & 2002 & $\odot$ & $?$ & & $?$ & $?$ & $?$ & $?$ \\
\hline Vuopala et al. [21] & 1969 & ○ & ○ & & C & $?$ & $?$ & $?$ \\
\hline Williams et al. [78] & 1985 & $?$ & $?$ & & $?$ & $?$ & $?$ & $?$ \\
\hline Zuurmond et al. [89] & 1996 & $?$ & $?$ & & $?$ & $?$ & $?$ & $?$ \\
\hline
\end{tabular}

Figure 2. Risk of bias in randomized controlled trials. 
European Blood and Marrow Transplant Group centers ${ }^{7}$. They had difficulties isolating the effects of DMSO from confounding factors such as cell breakdown products and conditioning chemotherapy. Factors such as age, gender, volume transfused, granulocyte concentration, clumping of transplant material, and amount of red blood cells played a role in the occurrence of adverse reactions ${ }^{61,86,120-122}$. Another study believed that acute volume expansion, electrolyte imbalance and vagal responses to the coldness of the freshly thawed infusate were more likely reasons for cardiac arrhythmias during stem cell transfusions than the DMSO infused ${ }^{123}$. This differs from other studies, which found a clear connection between dose of DMSO and occurrence of cardiac adverse reactions ${ }^{41,67,71,75,78,85,86,93,101,115}$. Therefore, it is possible that some adverse reactions are more or less common than found in this review. The rarer side effects are often reported in case reports, which often did not meet the eligibility criteria in this review. However, we have included several larger studies in this review, and they found a very small occurrence of serious adverse events ${ }^{7,55,66,74}$.
In conclusion, adverse reactions due to DMSO are often mild and transient and do not qualify as serious adverse events. Cardiovascular and respiratory adverse reactions occur mostly when DMSO is administered intravenously, whereas dermatological reactions have a higher incidence when DMSO is administered transdermally. An important finding is that the occurrence of adverse reactions seems to be related to the dose of DMSO, and it therefore seems safe to continue the use of DMSO in small doses.

\section{Data availability}

All data underlying the results are available as part of the article and no additional source data are required.

\section{Grant information}

The author(s) declared that no grants were involved in supporting this work.

\section{Supplementary material Supplementary File 1. Completed PRISMA harms checklist.}

Click here to access the data

1. Brown JH: Dimethyl sulfoxide (DMSO)--a unique therapeutic entity. Aviat Space Environ Med. 1982; 53(1): 82-8. PubMed Abstract

2. Brobyn RD: The human toxicology of dimethyl sulfoxide. Ann NY Acad Sci. 1975; 243: 497-506.

PubMed Abstract | Publisher Full Text

3. Swanson BN: Medical use of dimethyl sulfoxide (DMSO). Rev Clin Basic Pharm. 1985; 5(1-2): 1-33.

PubMed Abstract

4. Paul MM: Interval therapy with dimethyl sulfoxide. Ann NY Acad Sci. 1967; 141(1): 586-98.

PubMed Abstract | Publisher Full Text

5. Kulah A, Akar M, Baykut L: Dimethyl sulfoxide in the management of patient with brain swelling and increased intracranial pressure after severe closed head injury. Neurochirurgia (Stuttg). 1990; 33(6): 177-80. PubMed Abstract | Publisher Full Text

6. Rosenbaum EE, Herschler RJ, Jacob SW: Dimethyl Sulfoxide in Musculoskeletal Disorders. JAMA. 1965; 192: 309-13. PubMed Abstract | Publisher Full Text

7. Morris C, de Wreede L, Scholten M, et al:: Should the standard dimethyl sulfoxide concentration be reduced? Results of a European Group for Blood and Marrow Transplantation prospective noninterventional study on usage and side effects of dimethyl sulfoxide. Transfusion. 2014; 54(10): 2514-22. PubMed Abstract | Publisher Full Text

8. Peeker R, Haghsheno MA, Holmäng S, et al:: Intravesical bacillus CalmetteGuerin and dimethyl sulfoxide for treatment of classic and nonulcer interstitial cystitis: a prospective, randomized double-blind study. J Urol. 2000; 164(6): 1912-5, discussion 1915-6.

PubMed Abstract | Publisher Full Text

9. Amemori $\mathrm{S}$, Iwakiri $\mathrm{R}$, Endo $\mathrm{H}$, et al:: Oral dimethyl sulfoxide for systemic amyloid $\mathbf{A}$ amyloidosis complication in chronic inflammatory disease: a retrospective patient chart review. J Gastroenterol. 2006; 41(5): 444-9. PubMed Abstract | Publisher Full Text

10. Hucker HB, Miller JK, Hochberg A, et al.: Studies on the absorption, excretion and metabolism of dimethylsulfoxide (DMSO) in man. $J$ Pharmacol Exp Ther. 1967; 155(2): 309-17.

PubMed Abstract

11. Kligman AM: Topical Pharmacology and Toxicology of Dimethyl Sulfoxide. 1. JAMA. 1965; 193: 796-804.

PubMed Abstract | Publisher Full Text

12. Lovelock JE, Bishop MW: Prevention of freezing damage to living cells by dimethyl sulphoxide. Nature. 1959; 183(4672): 1394-5. PubMed Abstract | Publisher Full Text

13. Zorzela L, Loke YK, loannidis JP, et al.: PRISMA harms checklist: improving harms reporting in systematic reviews. BMJ. 2016; 352: i157. PubMed Abstract | Publisher Full Text

14. Wells G, Shea B, O'Connell D, et al:: The Newcastle-Ottawa Scale (NOS) for assessing the quality of nonrandomised studies in meta-analyses. Reference Source

15. Higgins JPT, Altman DG, Sterne JAC: Chapter 8: Assessing risk of bias in included studies. In: Higgins JPT GS. Cochrane Handbook for Systematic Reviews of Interventions Version 5.1.0 (updated March 2011). The Cochrane Collaboration. 2008. Publisher Full Text

16. Vadhan-Raj S, Kavanagh JJ, Freedman RS, et al.: Safety and efficacy of transfusions of autologous cryopreserved platelets derived from recombinant human thrombopoietin to support chemotherapy-associated severe thrombocytopenia: a randomised cross-over study. Lancet. 2002; 359(9324): 2145-52.

PubMed Abstract | Publisher Full Text

17. Ogden HD: Experiences with DMSO in treatment of headache. Ann NY Acad Sci. 1967; 141(1): 646-8. PubMed Abstract | Publisher Full Text

18. Martin-Henao GA, Resano PM, Villegas JM, et al.: Adverse reactions during transfusion of thawed haematopoietic progenitor cells from apheresis are closely related to the number of granulocyte cells in the leukapheresis product. Vox Sang. 2010; 99(3): 267-73. PubMed Abstract | Publisher Full Text 
19. Savastano AA: Clinical experiences with dimethyl sulfoxide (DMSO) in human subjects. Approval must be withheld until safety in extended use is established. R I Med J. 1984; 67(3): 119-21.

PubMed Abstract

20. Ivanov OL, Potekaev NS, Aliab'eva AP: [Dimethyl sulfoxide applications in the treatment of erythema nodosum]. Ter Arkh. 1983; 55(9): 104-7. PubMed Abstract

21. Vuopala U, Isomäki H, Kaipainen WJ: Dimethyl sulfoxide (DMSO) ointment in the treatment of rheumatoid arthritis. A double blind study. Acta Rheumatol Scand. 1969; 15(2): 139-44.

PubMed Abstract | Publisher Full Text

22. Menne T: Nickel allergy--reliability of patch test. Evaluated in female twins. Derm Beruf Umwelt. 1981; 29(6): 156-60. PubMed Abstract

23. Castillo N, Garcia-Cadenas I, Garcia O, et al.: Few and nonsevere adverse infusion events using an automated method for diluting and washing before unrelated single cord blood transplantation. Biol Blood Marrow Transplant. 2015; 21(4): 682-7.

PubMed Abstract | Publisher Full Text

24. Pandhi R, Kaur I, Kumar B: Lack of effect of dimethylsulphoxide in cutaneous amyloidosis. J Dermatolog Treat. 2002: 13(1): 11-4. PubMed Abstract | Publisher Full Text

25. Halle $\mathrm{P}$, Tournilhac $\mathrm{O}$, Knopinska-Posluszny $\mathrm{W}$, et al.: Uncontrolled-rate freezing and storage at $\mathbf{- 8 0}$ degrees $\mathbf{C}$, with only 3.5 -percent DMSO in cryoprotective solution for 109 autologous peripheral blood progenitor cell transplantations. Transfusion. 2001; 41(5): 667-73.

PubMed Abstract | Publisher Full Tex

26. Syme R, Bewick M, Stewart D, et al.: The role of depletion of dimethyl sulfoxide before autografting: on hematologic recovery, side effects, and toxicity. Biol Blood Marrow Transplant. 2004; 10(2): 135-41. PubMed Abstract | Publisher Full Text

27. Ozdemir E, Akgedik K, Akdogan S, et al.: The lollipop with strawberry aroma may be promising in reduction of infusion-related nausea and vomiting during the infusion of cryopreserved peripheral blood stem cells. Biol Blood Marrow Transplant 2008; 14(12): 1425-8. PubMed Abstract | Publisher Full Tex

28. Silvestri DL, Corey L, Holmes KK: Ineffectiveness of topical idoxuridine in dimethyl sulfoxide for therapy for genital herpes. JAMA. 1982; 248(8): 953-9. PubMed Abstract | Publisher Full Text

29. Shainhouse JZ, Grierson LM, Naseer Z: A long-term, open-label study to confirm the safety of topical diclofenac solution containing dimethyl sulfoxide in the treatment of the osteoarthritic knee. Am J Ther. 2010; 17(6): 566-76. PubMed Abstract | Publisher Full Text

30. Simon LS, Grierson LM, Naseer Z, et al.: Efficacy and safety of topical diclofenac containing dimethyl sulfoxide (DMSO) compared with those of topical placebo, DMSO vehicle and oral diclofenac for knee osteoarthritis. Pain. 2009; 143(3): 238-45.

PubMed Abstract | Publisher Full Tex

31. Engel MF: Dimethyl sulfoxide in the treatment of scleroderma. South Med J. 1972; 65(1): 71-3.

PubMed Abstract

32. Ludwig CU, Stoll HR, Obrist R, et al.: Prevention of cytotoxic drug induced skin ulcers with dimethyl sulfoxide (DMSO) and alpha-tocopherole. Eur J Cancer Clin Oncol. 1987; 23(3): 327-9.

PubMed Abstract | Publisher Full Text

33. Mitrus I, Smagur A, Fidyk W, et al:: Reduction of DMSO concentration in cryopreservation mixture from $10 \%$ to $7.5 \%$ and $5 \%$ has no impact on engraftment after autologous peripheral blood stem cell transplantation: results of a prospective, randomized study. Bone Marrow Transplant. 2018; 53(3): 274-280.

PubMed Abstract | Publisher Full Text

34. Elhammady MS, Wolfe $\mathrm{SQ}$, Farhat $\mathrm{H}$, et al:: Onyx embolization of carotidcavernous fistulas. J Neurosurg. 2010; 112(3): 589-94.

PubMed Abstract | Publisher Full Tex

35. Hung MJ, Chen YT, Shen PS, et al.: Risk factors that affect the treatment of interstitial cystitis using intravesical therapy with a dimethyl sulfoxide cocktail. Int Urogynecol J. 2012; 23(11): 1533-9.

PubMed Abstract | Publisher Full Text

36. Lemarie C, Camels B, Malenfant C, et al:: Clinical experience with the delivery of thawed and washed autologous blood cells, with an automated closed fluid management device: CytoMate. Transfusion. 2005; 45(5): 737-42. PubMed Abstract | Publisher Full Text

37. Mendelow AY, Forsyth A, Florence AT, et al.: Patch testing for nickel allergy The influence of the vehicle on the response rate to topical nickel sulphate. Contact Dermatitis. 1985; 13(1): 29-33. PubMed Abstract | Publisher Full Text

38. Fowler JE Jr: Prospective study of intravesical dimethyl sulfoxide in treatment of suspected early interstitial cystitis. Urology. 1981; 18(1): 21-6. PubMed Abstract | Publisher Full Tex

39. Perseghin $\mathrm{P}$, Balduzzi A, Bonanomi S, et al:: Infusion-related side-effects in children undergoing autologous hematopoietic stem cell transplantation for acute leukemia. Bone Marrow Transplant. England; 2000; 26(1): 116-8. PubMed Abstract | Publisher Full Text
40. Rowley SD, Feng Z, Yadock D, et al.: Post-thaw removal of DMSO does no completely abrogate infusional toxicity or the need for pre-infusion histamine blockade. Cytotherapy. 1999; 1(6): 439-46.

PubMed Abstract | Publisher Full Text

41. Davis J, Rowley SD, Santos GW: Toxicity of autologous bone marrow graft infusion. Prog Clin Biol Res. 1990; 333: 531-40.

PubMed Abstract

42. Bertelli G, Gozza A, Forno GB, et al: Topical dimethylsulfoxide for the prevention of soft tissue injury after extravasation of vesicant cytotoxic drugs: a prospective clinical study. J Clin Oncol. 1995; 13(11): 2851-5.

PubMed Abstract | Publisher Full Text

43. Barker SB, Matthews PN, Philip PF, et al.: Prospective study of intravesica dimethyl sulphoxide in the treatment of chronic inflammatory bladder disease. Br J Urol. 1987; 59(2): 142-4.

PubMed Abstract | Publisher Full Tex

44. Tseraidis GS, Popova SS, Zykova Nla: [Use of a progesterone ointment in hirsutism]. Vestn Dermatol Venerol. 1986; (7): 14-7. PubMed Abstract

45. Scherbel AL, McCormack LJ, Layle JK: Further observations on the effect of dimethyl sulfoxide in patients with generalized scleroderma. (Progressive systemic sclerosis). Ann N Y Acad Sci. 1967; 141(1): 613-29. PubMed Abstract | Publisher Full Text

46. Mitrus I, Smagur A, Giebel S, et al.: A faster reconstitution of hematopoiesis after autologous transplantation of hematopoietic cells cryopreserved in $7.5 \%$ dimethyl sulfoxide if compared to $10 \%$ dimethyl sulfoxide containing medium. Cryobiology. 2013; 67(3): 327-31.

PubMed Abstract | Publisher Full Text

47. Mueller LP, Theurich S, Christopeit M, et al:: Neurotoxicity upon infusion of dimethylsulfoxide-cryopreserved peripheral blood stem cells in patients with and without pre-existing cerebral disease. Eur J Haematol. 2007; 78(6): 527-31. PubMed Abstract | Publisher Full Text

48. Gonella S, Di Giulio P: Delayed chemotherapy-induced nausea and vomiting in autologous hematopoietic cell transplant patients: an exploratory analysis. Tumori. 2015; 101(6): e154-9.

PubMed Abstract | Publisher Full Text

49. Cervigni $M$, Sommariva $M$, Tenaglia $R$, et al.: A randomized, open-label, multicenter study of the efficacy and safety of intravesical hyaluronic acid and chondroitin sulfate versus dimethyl sulfoxide in women with bladder pain syndrome/interstitial cystitis. Neurourol Urodyn. 2017; 36(4): 1178-86. PubMed Abstract | Publisher Full Text

50. Vuopala U, Kaipainen WJ: DMOS in the treatment of Dupuytren's contracture. A therapeutic experiment. Acta Rheumatol Scand. 1971; 17(1): 61-2. PubMed Abstract | Publisher Full Text

51. Okamoto $\mathrm{Y}$, Takaue $\mathrm{Y}$, Saito $\mathrm{S}$, et al.: Toxicities associated with cryopreserved and thawed peripheral blood stem cell autografts in children with active cancer. Transfusion. 1993; 33(7): 578-81. PubMed Abstract | Publisher Full Text

52. Zuckner J, Uddin J, Gantner GE Jr: Local application of dimethyl sulfoxide and DMSO combined with triamcinolone acetonide in rheumatoid arthritis. Ann NY Acad Sci. 1967; 141(1): 555-9.

PubMed Abstract | Publisher Full Text

53. Akkök CA, Liseth K, Nesthus I, et al.: Autologous peripheral blood progenitor cells cryopreserved with 5 and 10 percent dimethyl sulfoxide alone give comparable hematopoietic reconstitution after transplantation. Transfusion. 2008; 48(5): 877-83.

PubMed Abstract | Publisher Full Text

54. Davis JM, Rowley SD, Braine HG, et al.: Clinical toxicity of cryopreserved bone marrow graft infusion. Blood. 1990; 75(3): 781-6.

PubMed Abstract

55. Roth SH, Shainhouse JZ: Efficacy and safety of a topical diclofenac solution (pennsaid) in the treatment of primary osteoarthritis of the knee: randomized, double-blind, vehicle-controlled clinical trial. Arch Intern Med. 2004; 164(18): 2017-23.

PubMed Abstract | Publisher Full Text

56. Galmés A, Besalduch J, Bargay J, et al.: A simplified method for cryopreservation of hematopoietic stem cells with -80 degrees $C$ mechanica freezer with dimethyl sulfoxide as the sole cryoprotectant. Leuk Lymphoma. 1995; 17(1-2): 181-4.

PubMed Abstract | Publisher Full Text

57. Bookman AA, Williams KS, Shainhouse JZ: Effect of a topical diclofenac solution for relieving symptoms of primary osteoarthritis of the knee: a randomized controlled trial. CMAJ. 2004; 171(4): 333-8.

PubMed Abstract | Publisher Full Text | Free Full Text

58. Aliab'eva AP, Melikhova NI, Murav'ev luV: [Use of heparin applications in a dimethyl sulfoxide medium in the overall treatment of rheumatoid arthritis in children]. Pediatriia. 1980; (9): 50-1.

PubMed Abstract

59. Shpall EJ, LeMaistre CF, Holland K, et al.: A prospective randomized trial of buffy coat versus CD34-selected autologous bone marrow support in high-risk breast cancer patients receiving high-dose chemotherapy. Blood. 1997; 90(11): 4313-20.

PubMed Abstract

60. Fuks JZ, Egorin MJ, Aisner J, et al.: Cyclophosphamide and dimethylsulfoxide in 
the treatment of squamous carcinoma of the lung. Therapeutic efficacy, toxicity, and pharmacokinetics. Cancer Chemother Pharmacol. 1981; 6(2): 117-20. PubMed Abstract | Publisher Full Text

61. Styler MJ, Topolsky DL, Crilley PA, et al:: Transient high grade heart block following autologous bone marrow infusion. Bone Marrow Transplant. 1992; 10(5): 435-8.

PubMed Abstract

62. Marshall LF, Camp PE, Bowers SA: Dimethyl sulfoxide for the treatment of intracranial hypertension: a preliminary trial. Neurosurgery. 1984; 14(6): 659-63. PubMed Abstract | Publisher Full Text

63. Engel MF: Dimethyl sulfoxide (DMSO) in clinical dermatology. South Med J. 1966; 59(11): 1318-9.

PubMed Abstract

64. Roth SH, Fuller P: Pooled safety analysis of diclofenac sodium topical solution $1.5 \%(w / w)$ in the treatment of osteoarthritis in patients aged 75 years or older. Clin Interv Aging. 2012; 7: 127-37.

PubMed Abstract | Publisher Full Text | Free Full Text

65. Lv X, Jiang C, Li Y, et al:: Percutaneous transvenous packing of cavernous sinus with Onyx for cavernous dural arteriovenous fistula. Eur J Radiol. 2009; 71(2): 356-62.

PubMed Abstract | Publisher Full Text

66. Demos $\mathrm{CH}$, Beckloff GL, Donin MN, et al:: Dimethyl sulfoxide in musculoskeleta disorders. Ann N Y Acad Sci. 1967; 141(1): 517-23.

PubMed Abstract | Publisher Full Text

67. Spruance SL, Stewart JC, Freeman DJ, et al: Early application of topical $15 \%$ idoxuridine in dimethyl sulfoxide shortens the course of herpes simplex labialis: a multicenter placebo-controlled trial. J Infect Dis. 1990; 161(2): 191-7. PubMed Abstract | Publisher Full Text

68. Bojanic I, Cepulic BG, Mazic S, et al:: Toxicity related to autologous peripheral blood haematopoietic progenitor cell infusion is associated with number of granulocytes in graft, gender and diagnosis of multiple myeloma. Vox Sang. 2008; 95(1): 70-5.

PubMed Abstract | Publisher Full Text

69. Blumenthal LS, Fuchs M: The clinical use of dimethyl sulfoxide on various headaches, musculoskeletal, and other general medical disorders. Ann NY Acad Sci. 1967; 141(1): 572-85.

PubMed Abstract | Publisher Full Text

70. Hoang BX, Le BT, Tran HD, et al:: Dimethyl sulfoxide-sodium bicarbonate infusion for palliative care and pain relief in patients with metastatic prostate cancer. J Pain Palliat Care Pharmacother. 2011; 25(4): 350-5.

PubMed Abstract | Publisher Full Text

71. Stroncek DF, Fautsch SK, Lasky LC, et al.: Adverse reactions in patients transfused with cryopreserved marrow. Transfusion. 1991; 31(6): 521-6. PubMed Abstract | Publisher Full Text

72. Kaidbey $\mathrm{KH}$ : Therapy of resistant psoriasis with topical corticosteroids and dimethylsulfoxide. Dermatologica. 1976; 152(5): 316-20. PubMed Abstract | Publisher Full Text

73. Zambelli A, Poggi G, Da Prada G, et al: Clinical toxicity of cryopreserved circulating progenitor cells infusion. Anticancer Res. 1998; 18(6B): 4705-8. PubMed Abstract

74. Otrock ZK, Sempek DS, Carey S, et al:: Adverse events of cryopreserved hematopoietic stem cell infusions in adults: a single-center observational study. Transfusion. 2017; 57(6): 1522-6.

PubMed Abstract | Publisher Full Text

75. Matsumoto J: Clinical trials of dimethyl sulfoxide in rheumatoid arthritis patients in Japan. Ann NY Acad Sci. 1967; 141(1): 560-8. PubMed Abstract | Publisher Full Text

76. Melikhova NI, Murav'ev luV, Sigidin laA, et al.: [Effectiveness of the treatment of juvenile rheumatoid arthritis with dimethyl sulfoxide gel]. Pediatriia. 1986; (6): 53-4.

PubMed Abstract

77. Holbro A, Graf L, Topalidou M, et al:: Cryopreserved stem cell products containing dimethyl sulfoxide lead to activation of the coagulation system without any impact on engraftment. Transfusion. 2014; 54(6): 1508-14. PubMed Abstract | Publisher Full Text

78. Williams HJ, Furst DE, Dahl SL, et al.: Double-blind, multicenter controlled trial comparing topical dimethyl sulfoxide and normal saline for treatment of hand ulcers in patients with systemic sclerosis. Arthritis Rheum. 1985; 28(3): 308-14. PubMed Abstract | Publisher Full Text

79. Simpson JR: Idoxuridine in the treatment of herpes zoster. Practitioner. 1975; 215(1286): 226-9. PubMed Abstract

80. Lv X, Li Y, Jiang C, et al:: The incidence of trigeminocardiac reflex in endovascular treatment of dural arteriovenous fistula with onyx. Interv Neuroradiol. 2010; 16(1): 59-63.

PubMed Abstract | Publisher Full Text | Free Full Text

81. Hoang BX, Tran DM, Tran HQ, et al.: Dimethyl sulfoxide and sodium bicarbonate in the treatment of refractory cancer pain. $J$ Pain Palliat Care Pharmacother. 2011; 25(1): 19-24.

PubMed Abstract | Publisher Full Text

82. Bosso JA, Spruance SL, Wenerstrom G: Tolerance and percutaneous absorption of topically applied arildone. J Clin Pharmacol. 1985; 25(2): 95-9.

PubMed Abstract | Publisher Full Text
83. Ozkaya-Bayazit E, Kavak A, Güngör $\mathrm{H}$, et al.: Intermittent use of topical dimethyl sulfoxide in macular and papular amyloidosis. Int J Dermatol. 1998; 37(12): 949-54.

PubMed Abstract | Publisher Full Text

84. Vinnik CA, Jacob SW: Dimethylsulfoxide (DMSO) for human single-stage intraoperative tissue expansion and circulatory enhancement. Aesthetic Plast Surg. 1991; 15(4): 327-37.

PubMed Abstract | Publisher Full Text

85. Donmez A, Tombuloglu M, Gungor A, et al.: Clinical side effects during peripheral blood progenitor cell infusion. Transfus Apher Sci. 2007; 36(1): 95-101.

PubMed Abstract | Publisher Full Text

86. Cordoba R, Arrieta R, Kerguelen A, et al:: The occurrence of adverse events during the infusion of autologous peripheral blood stem cells is related to the number of granulocytes in the leukapheresis product. Bone Marrow Transplant. 2007; 40(11): 1063-7.

PubMed Abstract | Publisher Full Text

87. Alessandrino $\mathrm{P}$, Bernasconi $\mathrm{P}$, Caldera $\mathrm{D}$, et al:: Adverse events occurring during bone marrow or peripheral blood progenitor cell infusion: analysis of 126 cases. Bone Marrow Transplant. 1999; 23(6): 533-7.

PubMed Abstract | Publisher Full Text

88. Binnick SA, Shore SS, Corman A, et al:: Failure of dimethyl sulfoxide in the treatment of scleroderma. Arch Dermatol. 1977; 113(10): 1398-402. PubMed Abstract | Publisher Full Text

89. Zuurmond WW, Langendijk PN, Bezemer PD, et al:: Treatment of acute reflex sympathetic dystrophy with DMSO $50 \%$ in a fatty cream. Acta Anaesthesiol Scand. 1996; 40(3): 364-7.

PubMed Abstract | Publisher Full Text

90. Galmés A, Besalduch J, Bargay J, et al:: Cryopreservation of hematopoietic progenitor cells with 5 -percent dimethyl sulfoxide at -80 degrees $C$ without rate-controlled freezing. Transfusion. 1996; 36(9): 794-7.

PubMed Abstract | Publisher Full Text

91. Amiridze N, Darwish R: Hemodynamic instability during treatment of intracranial dural arteriovenous fistula and carotid cavernous fistula with Onyx: preliminary results and anesthesia considerations. J Neurointerv Surg. 2009; 1(2): 146-50

PubMed Abstract | Publisher Full Text

92. Vinokurov VL, Zharinov GM, Val'kovich AA, et al: [The prevention of radiation injuries to the rectum and bladder in cervical cancer patients]. Vopr Onkol. 1990; 36(9): 1119-20.

PubMed Abstract

93. Percy EC, Carson JD: The use of DMSO in tennis elbow and rotator cuff tendonitis: a double-blind study. Med Sci Sports Exerc. 1981; 13(4): 215-9. PubMed Abstract

94. Weigel BJ, Blaney SM, Reid JM, et al.: A phase I study of 17allylaminogeldanamycin in relapsed/refractory pediatric patients with solid tumors: a Children's Oncology Group study. Clin Cancer Res. 2007; 13(6): 1789-93.

PubMed Abstract | Publisher Full Text

95. Dawber R: Idoxuridine in herpes zoster: further evaluation of intermittent topical therapy. Br Med J. 1974; 2(5918): 526-7.

PubMed Abstract | Publisher Full Text | Free Full Text

96. Perez RS, Zuurmond WW, Bezemer PD, et al.: The treatment of complex regional pain syndrome type I with free radical scavengers: a randomized controlled study. Pain. 2003; 102(3): 297-307.

PubMed Abstract | Publisher Full Text

97. Stav K, Beberashvili I, Lindner A, et al:: Predictors of response to intravesical dimethyl-sulfoxide cocktail in patients with interstitial cystitis. Urology. 2012; 80(1): 61-5.

PubMed Abstract | Publisher Full Text

98. Duijvestein M, Vos AC, Roelofs $\mathrm{H}$, et al:: Autologous bone marrow-derived mesenchymal stromal cell treatment for refractory luminal Crohn's disease: results of a phase I study. Gut. 2010; 59(12): 1662-9. PubMed Abstract | Publisher Full Text

99. Marcacci G, Corazzelli G, Becchimanzi C, et al:: DMSO-associated encephalopathy during autologous peripheral stem cell infusion: a predisposing role of preconditioning exposure to CNS-penetrating agents? Bone Marrow Transplant. England, 2009; 44(2): 133-5. PubMed Abstract | Publisher Full Text

100. Rabinov JD, Yoo AJ, Ogilvy CS, et al.: ONYX versus $\mathrm{n}$-BCA for embolization of cranial dural arteriovenous fistulas. J Neurointerv Surg. 2013; 5(4): 306-10. PubMed Abstract | Publisher Full Text

101. Milone G, Mercurio S, Strano A, et al:: Adverse events after infusions of cryopreserved hematopoietic stem cells depend on non-mononuclear cells in the infused suspension and patient age. Cytotherapy. 2007; 9(4): 348-55. PubMed Abstract | Publisher Full Text

102. Horacek JM, Jebavy L, Jakl M, et al.: Cardiovascular changes associated with infusion of hematopoietic cell grafts in oncohematological patients -- impact of cryopreservation with dimethylsulfoxide. Exp Oncol. 2009; 31(2): 121-2. PubMed Abstract

103. Murav'ev luV: [Treatment of rheumatoid synovitis by intra-articular administration of dimethyl sulfoxide and corticosteroids]. Ter Arkh. 1986; 58(7): 104-5. PubMed Abstract 
104. Akkok CA, Holte MR, Tangen JM, et al.: Hematopoietic engraftment of dimethyl sulfoxide-depleted autologous peripheral blood progenitor cells. Transfusion. 2009; 49(2): 354-61.

PubMed Abstract | Publisher Full Text

105. Rössberger J, Fall M, Peeker R: Critical appraisal of dimethyl sulfoxide treatment for interstitial cystitis: discomfort, side-effects and treatment outcome. Scand J Urol Nephrol. 2005; 39(1): 73-7. PubMed Abstract | Publisher Full Text

106. Burton WJ, Gould PW, Hursthouse MW, et al:: A multicentre trial of Zostrum (5 percent idoxuridine in dimethyl sulphoxide) in herpes zoster. $N Z$ Med J. 1981; 94(696): 384-6. PubMed Abstract

107. Lockie LM, Norcross BM: A clinical study on the effects of dimethyl sulfoxide in 103 patients with acute and chronic musculoskeletal injuries and inflammations. Ann N Y Acad Sci. 1967; 141(1): 599-602. PubMed Abstract | Publisher Full Text

108. Evstaf'ev VV: [The use of a heparin ointment in combination with dimexide in treating psoriasis]. Vestn Dermatol Venerol. 1989; (9): 71-2. PubMed Abstract

109. Parsons JL, Shepard WL, Fosdick WM: DMSO an adjutant to physical therapy in the chronic frozen shoulder. Ann NY Acad Sci. 1967; 141(1): 569-71. PubMed Abstract | Publisher Full Text

110. Delaney C, Milano F, Cicconi L, et al.: Infusion of a non-HLA-matched ex-vivo expanded cord blood progenitor cell product after intensive acute myeloid leukaemia chemotherapy: a phase 1 trial. Lancet Haematol. 2016; 3(7): e330-9. PubMed Abstract | Publisher Full Text

111. Stewart BH: Dimethyl sulfoxide (DMSO) in the treatment of troublesome genitourinary disorders: a preliminary report. Cleve Clin Q. 1966; 33(2): 81-4. PubMed Abstract

112. Olver IN, Aisner J, Hament A, et al.: A prospective study of topical dimethy sulfoxide for treating anthracycline extravasation. J Clin Oncol. 1988; 6(11): $1732-5$.

PubMed Abstract | Publisher Full Text

113. Brown JH: Clinical experience with DMSO in acute musculoskeletal condition comparing a noncontrolled series with a controlled double blind study. Ann N Y Acad Sci. 1967; 141(1): 496-505. PubMed Abstract | Publisher Full Text

114. Garcia CA: Ocular toxicology of dimethyl sulfoxide and effects on retinitis pigmentosa. Ann NY Acad Sci. 1983; 411: 48-51. PubMed Abstract | Publisher Full Text

115. Kim DH, Jamal N, Saragosa R, et al.: Similar outcomes of cryopreserved allogeneic peripheral stem cell transplants (PBSCT) compared to fresh allografts. Biol Blood Marrow Transplant. 2007; 13(10): 1233-43. PubMed Abstract | Publisher Full Text

116. Salim AS: Role of oxygen-derived free radical scavengers in the treatment of recurrent pain produced by chronic pancreatitis. A new approach. Arch Surg. 1991; 126(9): 1109-14

PubMed Abstract | Publisher Full Text

117. Martino M, Morabito F, Messina G, et al.: Fractionated infusions of cryopreserved stem cells may prevent DMSO-induced major cardiac complications in graft recipients. Haematologica. 1996; 81(1): 59-61. PubMed Abstract

118. Eisenberg S, Wickline M, Linenberger M, et al.: Prevention of dimethylsulfoxiderelated nausea and vomiting by prophylactic administration of ondansetron for patients receiving autologous cryopreserved peripheral blood stem cells. Oncol Nurs Forum. 2013; 40(3): 285-92. PubMed Abstract | Publisher Full Text

119. Gonella S, Berchialla $\mathrm{P}$, Bruno B, et al:: Are orange lollies effective in preventing nausea and vomiting related to dimethyl sulfoxide? A multicenter randomized trial. Support Care Cancer. 2014; 22(9): 2417-24.

PubMed Abstract | Publisher Full Text

120. Kessinger A, Schmit-Pokorny K, Smith D, et al:: Cryopreservation and infusion of autologous peripheral blood stem cells. Bone Marrow Transplant. 1990; 5 Suppl 1 $25-7$. PubMed Abstract

121. Foïs E, Desmartin M, Benhamida S, et al.: Recovery, viability and clinical toxicity of thawed and washed haematopoietic progenitor cells: analysis of 952 autologous peripheral blood stem cell transplantations. Bone Marrow Transplant. 2007; 40(9): 831-5. PubMed Abstract | Publisher Full Text

122. Calmels B, Lemarié C, Esterni B, et al:: Occurrence and severity of adverse events after autologous hematopoietic progenitor cell infusion are related to the amount of granulocytes in the apheresis product. Transfusion. 2007; 47(7): 1268-75. PubMed Abstract | Publisher Full Text

123. Keung YK, Lau S, Elkayam U, et al:: Cardiac arrhythmia after infusion of cryopreserved stem cells. Bone Marrow Transplant. 1994; 14(3): 363-7. PubMed Abstract 


\section{Open Peer Review}

\section{Current Peer Review Status: ? ?}

\section{Version 1}

Reviewer Report 21 March 2019

https://doi.org/10.5256/f1000research.18188.r45643

(C) 2019 Onakpoya I. This is an open access peer review report distributed under the terms of the Creative Commons Attribution License, which permits unrestricted use, distribution, and reproduction in any medium, provided the original work is properly cited.

\section{Igho J. Onakpoya}

Centre for Evidence-based Medicine, Nuffield Department of Primary Care Health Sciences, University of Oxford, Oxford, UK

The authors have conducted a systematic review assessing reports of adverse reactions attributed to DMSO. The topic is interesting, and the authors have conducted their searches in a reasonable way. However, there are several flaws in this manuscript that need to be addressed:

\section{Introduction}

The term "possible adverse reactions" is incorrect. Suspected adverse reactions is more reasonable

\section{Methods}

If Russian articles were screened by only one author, how were discrepancies resolved in these cases? Specify which authors extracted the data, and whether this was done

\section{Results} independently.

- The term "possibly due" is incorrect. There are 4 levels in describing associations between medicines and suspected adverse reactions. The authors should revise their terminology.

- You state "in some studies patients discontinued treatments due to halitosis"; however, you

Discussion have provided references for 5 studies - the report can be more precise.

How does "including Russian studies" strengthen the review? What about several other languages that have been omitted?

You state that there seems to be a dose-response relationship, and have drawn similar conclusions. However, at no point in the results do you report data to support this claim. You state that studies reported associations between dose and the occurrence of adverse reactions, but fail to report the doses in question.

Please enumerate the limitations of your review.

Are the rationale for, and objectives of, the Systematic Review clearly stated? 
Yes

Are sufficient details of the methods and analysis provided to allow replication by others? Partly

Is the statistical analysis and its interpretation appropriate?

Partly

Are the conclusions drawn adequately supported by the results presented in the review? Partly

Competing Interests: No competing interests were disclosed.

Reviewer Expertise: Adverse drug reactions; systematic reviews

I confirm that I have read this submission and believe that I have an appropriate level of expertise to confirm that it is of an acceptable scientific standard, however I have significant reservations, as outlined above.

Author Response 31 Jul 2019

bennedikte Madsen, Herlev Hospital, Herlev, Denmark

Dear Igho J. Onakpoya,

Thank your for reviewing our manuscript "Adverse reactions of dimethyl sulfoxide in humans: a systematic review". Your comments were very helpful and we appreciate the effort you put in to reviewing our manuscript. We have addressed the individual questions in the section below. We hope your find our replies satisfactory. Questions are written in italic and answers in plain.

Q1: The term "possible adverse reactions" is incorrect. Suspected adverse reactions is more reasonable.

A1: We have changed the paragraph in the introduction section to "suspected adverse reactions".

Q2: If Russian articles were screened by only one author, how were discrepancies resolved in these cases? Specify which authors extracted the data, and whether this was done independently. A1: We have clarified in the manuscript how the screening process was performed: "Two authors (B.K.M. and D.Z.) independently screened title and abstract according to the eligibility criteria using www.covidence.org. Discrepancies were resolved by discussion. One author screened the full-text articles (B.K.M.). Russian articles were screened by an author fluent in Russian (M.H.). If M.H was in doubt regarding inclusion of a study the results were presented to B.K.M and then discussed until a mutual decision was made. After the screening process was finished, all included studies were imported to an Excel sheet (Microsoft Excel 2016). Data extraction was performed by two authors (M.H. extracted from the Russian articles and B.K.M. extracted from the rest)."

Q3: The term "possibly due" is incorrect. There are 4 levels in describing associations between 
medicines and suspected adverse reactions. The authors should revise their terminology. A3: We have rewritten the paragraph so it now states: "Gastrointestinal adverse reactions were reported in 61 studies. Of these, 10 studies were randomized controlled trials."

Q4: You state "in some studies patients discontinued treatments due to halitosis"; however, you have provided references for 5 studies - the report can be more precise

A4: We have made our report more precise and it now states: "In five studies, patients discontinued treatment due to halitosis."

Q5: How does "including Russian studies" strengthen the review? What about several other languages that have been omitted?

A5: A Russian Chemist, Dr. Alexander Saytzeff, identified DMSO in 1866, however it was not used for medical use at the time1. But the fact that he was Russian might have been the reason why Russian scientists have made numerous studies using DMSO. We therefore thought it would be valuable to include Russian articles since many of these studies have never been translated, and therefore are not available to the international scientific society. Of course, we could have included many other languages, but we thought it most relevant to include Russian since we observed a large amount of articles in Russian during our initial examination of the subject.

Q6: You state that there seems to be a dose-response relationship and have drawn similar conclusions. However, at no point in the results do you report data to support this claim. You state that studies reported associations between dose and the occurrence of adverse reactions but fail to report the doses in question.

A6: As mentioned in our study several studies described a dose-response relationship between the amount of DMSO and the occurrence of adverse reactions $(26 \cdot 33 \cdot 41 \cdot 53 \cdot 67 \cdot 71,73 \cdot 75$ $178,83^{\prime} 85^{\prime} 86,93^{\prime} 101 \cdot 115$ ). However, since the doses of DMSO and the route of administration differ between the studies, we were not able to give an exact dose. We can only say that an association seems likely.

Q7: Please enumerate the limitations of your review

A7: We have enumerated the limitations listed in the discussion in the manuscript.

Competing Interests: No competing interests were disclosed.

Reviewer Report 05 February 2019

https://doi.org/10.5256/f1000research.18188.r40223

(c) 2019 Morris C. This is an open access peer review report distributed under the terms of the Creative Commons Attribution License, which permits unrestricted use, distribution, and reproduction in any medium, provided the original work is properly cited.

\section{Curly Morris}


Centre for Cancer Research and Cell Biology (CCRCB), Queen's University Belfast, Belfast, UK

With well over 20,000 patients receiving DMSO based autologous transplants annually in Europe alone, this is a timely review of the toxic effects of this valuable agent. It has been performed in an appropriate and scholarly manner and brings added value by including the Russian literature not easily accessible to the average English-speaking reader.

However there are ways in which the review might be improved and give added value to the reader.

It is not easy to ascertain the number of patients receiving DMSO intravenously and those receiving it by other routes. A small table could clarify this.

The side effect tables either as numbers of patients or numbers of treatments. If they cannot be presented as one combined set of data then some explanation of the two separate tables would be beneficial.

There seems to have been no attempt to quantify the dose of DMSO which patients have received or to characterize the severity of the reactions and relate these. Furthermore DMSO is usually a vehicle to facilitate giving the patient some other treatment e.g. a stem cell transplant or drug so the reasons for the use of DMSO are not clear. This also means there are side effects from the drug or treatment facilitated by the DMSO; is it possible to separate these effects in any way? Do the authors of the many papers selected for analysis recommend an upper limit to the amount of DMSO given or have a strategy for minimising the dose?

In their final paragraph the authors suggest that "reactions due to DMSO are often mild and transient". In their previous paragraph they admit that the case reports the less common and more severe side effects which did not meet the eligibility criteria of this review. However as long ago as 2005 it was possible to identify severe side effects in an appreciable number of cases (Windrum et al., 2005 ${ }^{1}$ ). Furthermore although they do not separate the factors responsible the authors of reference 7 record a SAE (Grades 3, 4 and 5) profile in excess of 3\%. The authors should possibly be a little more circumspect in this paragraph particularly as they recommend the use of DMSO in (unspecified) small doses.

\section{References}

1. Windrum P, Morris TC, Drake MB, Niederwieser D, et al.: Variation in dimethyl sulfoxide use in stem cell transplantation: a survey of EBMT centres.Bone Marrow Transplant. 2005; 36 (7): 601-3

PubMed Abstract | Publisher Full Text

Are the rationale for, and objectives of, the Systematic Review clearly stated? Yes

Are sufficient details of the methods and analysis provided to allow replication by others? Yes

Is the statistical analysis and its interpretation appropriate?

Not applicable 
Are the conclusions drawn adequately supported by the results presented in the review? Yes

Competing Interests: No competing interests were disclosed.

Reviewer Expertise: haematology, myeloma, autologous transplantation

I confirm that I have read this submission and believe that I have an appropriate level of expertise to confirm that it is of an acceptable scientific standard, however I have significant reservations, as outlined above.

Author Response 31 Jul 2019

bennedikte Madsen, Herlev Hospital, Herlev, Denmark

Dear Curly Morris,

Thank for reviewing our manuscript: "Adverse reactions of dimethyl sulfoxide in humans: a systematic review". We appreciate the effort put into reviewing our manuscript, and we have tried our best to use your comments to improve our manuscript. We have addressed the individual questions in the section below. We hope your find our replies satisfactory. Questions are written in italic and answers in plain.

Q1: It is not easy to ascertain the number of patients receiving DMSO intravenously and those receiving it by other routes. A small table could clarify this.

A1: We have added a table (Table 9) to our manuscript describing the route of administration of DMSO.

Q2 \& 3: There seems to have been no attempt to quantify the dose of DMSO which patients have received or to characterize the severity of the reactions and relate these. Furthermore DMSO is usually a vehicle to facilitate giving the patient some other treatment e.g. a stem cell transplant or drug so the reasons for the use of DMSO are not clear. This also means there are side effects from the drug or treatment facilitated by the DMSO; is it possible to separate these effects in any way? Do the authors of the many papers selected for analysis recommend an upper limit to the amount of DMSO given or have a strategy for minimising the dose?

In their final paragraph the authors suggest that "reactions due to DMSO are often mild and transient". In their previous paragraph they admit that the case reports the less common and more severe side effects which did not meet the eligibility criteria of this review. However as long ago as 2005 it was possible to identify severe side effects in an appreciable number of cases (Windrum et al., 2005 ${ }^{1}$ ). Furthermore although they do not separate the factors responsible the authors of reference 7 record a SAE (Grades 3, 4 and 5) profile in excess of 3\%. The authors should possibly be a little more circumspect in this paragraph particularly as they recommend the use of DMSO in (unspecified) small doses.

A2 \& 3: DMSO is most often used as a vehicle in combination with other drugs. Therefore, it is not possible to separate completely the adverse reactions related to the use of DMSO and the adverse reactions related to other drugs, since adverse reactions such as nausea, vomiting, headache etc. are not specific for solely DMSO.

As described by the authors of reference 77 , it was difficult to isolate the effect of DMSO 
from side effects related to conditioning chemotherapy. The only adverse effect that can solely be attributed to DMSO is halitosis. Therefore, we could not conclude that DMSO was the cause of SAE's in reference 7 and have not included it in our study. Correctly, Windrum et al. ${ }^{1}$ describes several adverse reactions which may be contributed to DMSO. However, the study does not describe the seriousness of the adverse reactions.

As described in our study, it is very possible that some events are underrepresented in our study, which is a limitation.

The upper limit was not described by any studies; on the other hand several studies evaluated different doses of DMSO and found that a lesser amount of DMSO created fewer adverse reactions ( $61,86,120-122$.). Based on this observation, we feel confident that the use of small amounts of DMSO is recommendable, since DMSO works well as a vehicle. However, limiting the amount would always be desirable.

Competing Interests: No competing interests were disclosed.

The benefits of publishing with F1000Research:

- Your article is published within days, with no editorial bias

- You can publish traditional articles, null/negative results, case reports, data notes and more

- The peer review process is transparent and collaborative

- Your article is indexed in PubMed after passing peer review

- Dedicated customer support at every stage

For pre-submission enquiries, contact research@f1000.com 